\title{
Utilization of Construction and Demolition Waste and Environmental Management Practice in South East Asian Countries
}

\author{
Hui Yee Ngieng ${ }^{1}$, Tony Hadibarata ${ }^{1 *}$, Rubiyatno ${ }^{2}$ \\ ${ }^{1}$ Department of Environmental Engineering, Faculty of Engineering and Science, Curtin University Malaysia, CDT 250, Miri \\ 98009, Malaysia \\ ${ }^{2}$ Interdisciplinary Graduate School of Medicine and Engineering, University of Yamanashi, Kofu, 400-0015, Japan \\ Corresponding Author: hadibarata@curtin.edu.my
}

SUBMITTED: 10 May 2021; REVISED: 11 June 2021; ACCEPTED: 13 June 2021

\begin{abstract}
The ASEAN population will increase to 724.8 million by the year 2030 and the urbanization rate increases with years. This leads to the development of the construction industry to fulfil the fundamental social and physical requirements. Construction activities create an adverse negative impact on the environment, such as pollution and damage to the environment. This article will study more about the construction and demolition waste (C\&D waste) and it can be founded in various construction stages. Therefore, the government and authorities introduce environmental management practices to mitigate the negative impact on construction on the environment and minimize the pollution at the source. What, why and where are terms required to consider before the implementation of environmental management practice. The government policies of Malaysia, Singapore and Thailand are summarized. Approximately $10 \%$ of total synthetic carbon dioxide $\left(\mathrm{CO}_{2}\right)$ sourced from concrete production. The content more emphasizes the green materials generated from agricultural waste to replace the silica in concrete. The bamboo is used as interior decoration and material for building construction. Green materials technology is solar panel, solar thermal collector, geothermal technology, hydropower technology and cooling roof system.
\end{abstract}

Keywords: construction industry; environmental management practices; green materials; green technology; ASEAN.

\section{Introduction}

With the rapid growth of population and industrialization, construction is one of the major industries which plays a significant role in contributing to the rapid growth of the economy in the Association of Southeast Asia Nations (ASEAN) countries in the past few decades. The construction of buildings serves as a shelter for humans, allowing humans to have better quality of life or provides business operations for people in business, which brings wealth to them. Some statistics showed that the construction industry contributes to the Gross Domestic Product (GDP) of ASEAN countries. In 2013, the GDP per capita of ASEAN countries such 
as Cambodia, Lao, Vietnam and Thailand were \$1008, \$1646, \$1911 and \$5779, respectively [1]. According to the statistic done by the Malaysia Government, the GDP of Malaysia demonstrated a declining trend in the year $2019(-4.3 \%)$ and $2020(-5.6 \%)$ since the decline in year 1998 and 2009 and also the GDP of the construction industry contracted 19.4\% in year 2020 compared with year 2019 [2]. In other words, the GDP of Malaysia indicated a positive trend most of the years. Even though GDP's value displayed a decreased trend because of the Coronavirus diseases (COVID-19), construction plays a prominent role in GDP growth. However, construction negatively impacts the environment; even so construction brings wealth and good life to humans. Three stages such as site preparation stage, construction stage and post construction stage create waste and pollution to the environment. Construction works such as land excavation, roadworks, building works, demolition and renovation [3]. Construction works destroy the natural environment which provides shelter for flora and fauna. At the postconstruction stage, construction waste which refers to the unwanted or destroyed waste pollutes the environment as the waste disposed of improbably. In order to reduce the impact of construction activities on the environment, environmental management practice has been introduced.

Recently, the idea of "Go Green" has been launched globally to solve environmental issues. "Green" refers to eco-friendly or environmentally friendly terms. Green construction materials also defined as green building material. In ASEAN, green material and green building are the common key terms to build a green environment and have sustainable construction. Green building is refer to utilization of green materials that are environmentally friendly to reduce resources and construction waste [4]. Green materials are renewable materials and the impact of material is considered throughout its life cycle [5]. Other than environmental benefit (e.g., reduce pollution, minimize site disturbance and conservation of resources), green materials also improve the indoor air quality of buildings and save expenses of waste disposal. The durability of green materials refers to the ability of materials to last longer without significant deterioration to conserve the resources, reduce waste, repair and replace the unit (Aghdam et al., 2018). Examples of green materials are mix with wool of sheep or cellulose for insulation purposes and external gypsum with a fibrous material, wooden panel, clay plaster mix with straw or plywood [6]. As technology evolves, the green materials are more sustainable, durable, non-toxic, and good in material properties [7].

Green building gave benefits to the environment through energy-efficient and sustainable construction. The introduction of green technology is to fulfill society's needs by not destroying or using up the natural resources on the Earth and creating outcomes that are more eco-friendly and able to mitigate the effect of climate change [8]. A few centuries ago, fossil fuel was the main energy source globally, and Vietnam might exceed China in the future as the government does not pay attention to this [9]. With the development of renewable technology, some of the countries had been replacing fossil fuel with solar, biomass, hydro etc. However, the fossil fuel energy still used as the renewable energy cannot sustain the demand of electricity during peak hour. 


\section{Construction Industry}

\subsection{Population and construction industry}

The total population in Southeast Asia increased over the years. The total population in 1985 was 401.7 million and raised to 633.5 million in 2015 while the total population will reach 724.8 million by 2030 [10]. With more population, the population in urban areas rise as well. A statistic based on the proportion of urban population to the total population in ASEAN countries was generated, the proportion expanded from $15.5 \%$ (1950) to $42 \%$ (2010) and this trend resulted in $50 \%$ by 2025 [11]. For example, in Thailand, the overall population of major cities increased from $31.39 \%$ (2000) to $49.95 \%$ (2018) [12]. This is known as urbanization. These statistics demonstrated more population will migrate to urban areas and contribute to development of urban areas. Hence, construction industry is one of the main mechanisms for infrastructure development to sustain urban expansion to more area and undergo development to fulfil the fundamental social and physical requirement.

\subsection{Impact of construction on the environment}

As construction industry must involve in construction of buildings (e.g., residential and commercial building), renovation on existing building and engineering projects (e.g., construction of road and bridge). In order to have these construction works, logging, earthworks and land clearing will be carried out. In the past, the average logging intensity was 9 trees per hectare [13]. Trees, shrubs or grassland are habitat for certain flora and fauna. Thus, flora and fauna on land facing loss of habitat problem. Construction activities in Malaysia influenced $67.5 \%$ of the ecosystem and $21 \%$ of natural resources [14]. The construction activities affect the ecosystem nearby the construction site. During the construction stage, operation of construction equipment, consumption of natural resources, and ancillary materials are the main source of pollution [15]. Furthermore, the construction industry contributes to greenhouse gases emission and acid rain [16]. From a different viewpoint, the operation of construction equipment creates noise pollution. After construction which means during building operation create a negative impact on the environment as well. Various aspects (e.g., usage of energy, pollution on the environment, maintenance of building and disposal of demolished wastes) are used to determine the negative impact of building on the environment [17].

\subsection{Construction waste}

Forty percent of materials were used in the building construction industry which is based on the global economy [16]. Timber wood was the main material used for construction centuries ago. Nowadays, timber wood is replaced with other suitable alternative materials (e.g., bricks, stones, concrete, ceramics, plastics, steel, aluminium, metal etc) to save cost and be more sustainable. Unfortunately, most of the alternative materials are not environmentally friendly. The yearly production of concrete used about 20 billion tons of raw materials and estimation of 18 billion tons of concrete per year will be used up by 2050. One of the construction materials such as cement contributes to carbon dioxide emission. A ton of cement emitted around $650 \mathrm{~kg}$ to $920 \mathrm{~kg}$ of carbon dioxide to the atmosphere [18]. 
The waste of the construction industry is known as construction and demolition waste (C\&D waste) and it can be found in various construction stages. An article defined that the waste produced from demolition stage at least 50 times compared with new construction [19]. A review article lists the amount of C\&D WASTE generated by different countries in 2014 and Fig. 1 summarized the amount of C\&D waste generated. Malaysia has the highest generation of C\&D waste in ASEAN in comparison with Vietnam, Thailand, Singapore and Myanmar. However, Malaysia is the second highest $C \& D$ waste generation country compared with China, Japan, USA, Germany and Slovenia. C\&D waste is considered as the main source of pollution. The government of the Southeast Asia countries launched some policies to solve the problem [20].

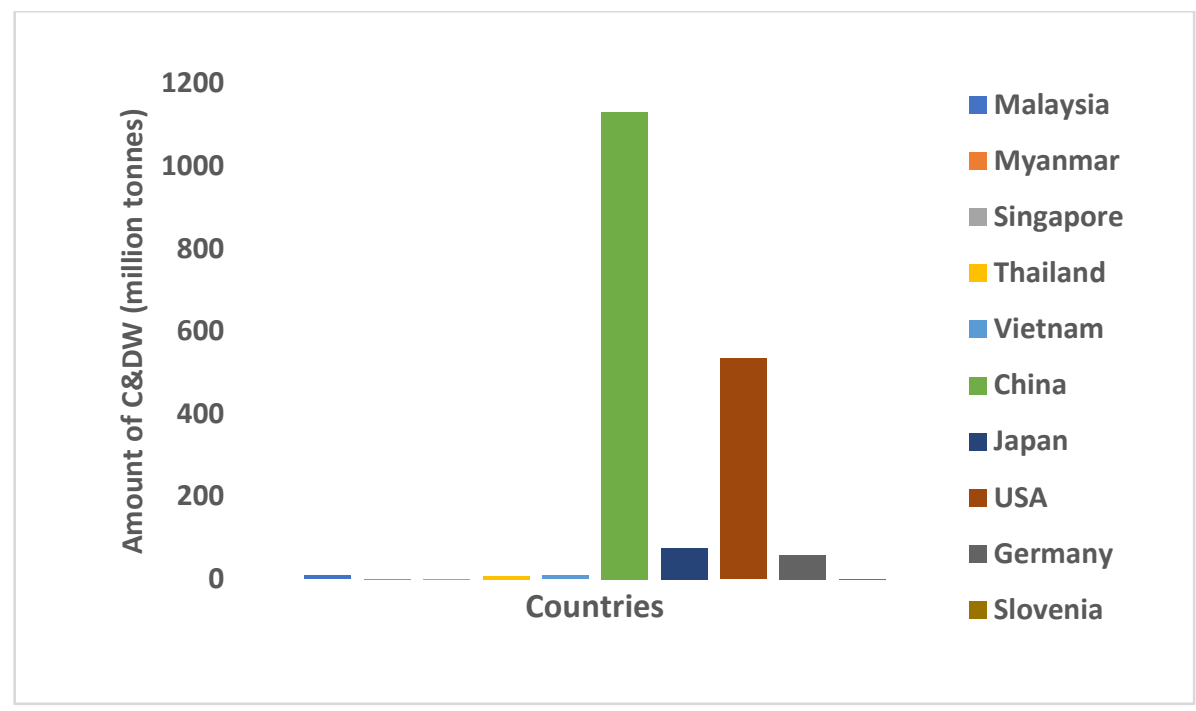

Figure 1: Amount of C\&D WASTE generated in different countries in 2014.

\section{Environmental Management Practices}

\subsection{Definition of environmental management practices}

Environmental management practices for construction had been applied globally. Historically, the term "environmental management practices" had been explained to minimize the pollution at the source through the level of resources spend in activities and understand the method of development which include the outcome of materials recycling, reduction of waste and implementation of environmental management systems (ISO14001) [21]. Previous study showed that the environmental management system is the techniques, guidelines and methods of firms which use to monitor and control the impact of their action on the natural environment. A reviewed article defined environmental management practices as an application of firms or organizations that use to remediate environmental pollution through waste management systems, reduce emission of carbon and use water or energy efficiently [22]. Most companies or enterprises implement environmental management practices such as environmental management services (EMS), life cycle analysis, industrial ecology and energy management to minimize the environmental impacts of daily operations [23]. In short, environmental management practices refer to the activities or action done by firms or organizations in order to eliminate the impact of pollution on the environment. In general, there are three terms required to consider before the implementation of environmental management practice which 
are what, why and where [23] . "What" refers to the detail of environmental management practice to be implemented to resolve the environmental problem, "why" refers to the reasons that brings to the application of environmental management practice and "where" refers to the target of environmental management practice whether it focuses on single and many environmental problems [24].

\subsection{Environmental management practices and sustainable development goals}

Environmental management practices are indirectly related to sustainable development. In order to achieve sustainable development, environmental management practices are one of the essential steps. The target of environmental management practice is to reduce the pollution on the environment where it contributes indirectly to sustainable development goals. Development goals such as clean water and sanitation, life below water or life on land. These goals are related to the environment and the ecosystem. Table 1 points out the target of goals which is related to the environment. Professional engineers play a main role to design an engineering solution to overcome the environment issue and achieve the sustainable development goals.

Table 1. Target of sustainable development goals [24]

\begin{tabular}{ll}
\hline Sustainable development goals & \multicolumn{1}{c}{ Target of goal } \\
\hline Clean water and sanitation & $\begin{array}{l}\text { Reduce, minimize or eliminate the pollution on the environment, dischargement of } \\
\text { poisonous chemicals and materials and trash to reduce half portion of contaminated } \\
\text { wastewater and significantly enhance the water recycling and safe reuse to enhance } \\
\text { the water quality globally by } 2030 .\end{array}$ \\
Life below water & $\begin{array}{l}\text { Control and minimize the pollution of land-based activities (e.g., marine debris and } \\
\text { nutrient pollution) to marine by } 2025 .\end{array}$ \\
Life on land & Conserve the mountain ecosystem by 2030. \\
\hline
\end{tabular}

\subsection{Environmental management practices and ISO 14000}

ISO 14000 is a global environmental standard which is a guideline target on environmental management of companies and organizations to reduce negative impact on the environment and enhance the performance in the environmental aspects. Within ISO 14000 standard, ISO 14001 is a global standard for environmental management system (EMS) which proposes environmental improvement into every company operation and provides a standardized approach to manage environmental problems [25].

\section{Government policy on Environmental Management Practices}

\subsection{Malaysia}

In regard to reduce the negative impact of construction on the environment, the government of countries executed lots of laws and regulations. Government of Malaysia had launched the Environment Quality Act (EQA) 1974 which was issued in 1974 as the dominant federal environment regulation and Environment Impact Assessment (EIA) procedures were introduced under EQA 1974 to highlight the preventative control in 1987 as well as the Department of Environment (DOE) was founded to enforce the Act [26]. The procedures of EIA in Malaysia are modified based on the National Environmental Policy Act (NEPA) 1969 of the United States [27]. The content of EQA 1974 must be proactive and flexible to adapt the 
new measures for challenging environmental issues and the content has been amended for many times to be in line with the aim of environment policy [28]. All construction projects in Malaysia must submit EIA reports written by the environmental consultant to related government agencies such as DOE and Natural Resources and Environment Board (NREB).

Other than that, in 2009, the government of Malaysia launched a green building policy named National Green Technology Policy (NGTP) and commenced the Green Building Index (GBI) subsequently. The NGTP focused on the energy sector, building sector, water and waste management sector and transportation sector. For the building sector, the green technology was applied in different regions (e.g., construction, management, maintenance and demolition of buildings) and had been central [29]. In fact, the conventional building construction negatively impacted the environment and green building was implemented to minimize the condition. The implementation of green industrial buildings in Malaysia is so far in the right direction to reduce energy consumption [30]. However, the operation of green buildings is relatively high in cost in this competitive market. To encourage the construction of green buildings, the government of Malaysia commenced some interesting policies like a series of green tax exemptions and reductions and investment incentives as listed in Table 2. With these tax incentives, construction companies in Malaysia target this benefit and develop more green buildings instead.

Table 2. Different tax incentives and investment incentive in Malaysia [31] Tax incentives and investment incentive

Cooperate tax incentive

- 100 percent statutory income tax exemption for granted pioneer companies for ten years.

- Companies with green certification can have a 5 years investment tax allowance on capital expenditure.

- Purchasing equipment from local manufactures or equipment that used to generate energy from renewable sources not produced locally are with import duty and sales tax exemption.

\section{Company tax incentive}

- Companies that generate renewable energy and use it by their own.

- Investment allowances for qualified capital expenditure incurred during the GBI certification process.

\section{Corporate tax incentive}

- Company that has high efficiency of energy conservation.

- 10 years of 100 percent statutory income tax exemption or investment tax allowance as a GBI certified qualified capital expenditure.

- Companies that use capital expenditure for their own use to conserve energy would receive investment tax allowances for GBI certified capital expenditure.

\section{Income tax or stamp duty}

- For a person or company certificates with GBI have tax exemption on additional capital expenditure.

- If the amount of exemption equals the additional cost to own a GBI certificate, then stamp duty exemption on the instruments of transfer of ownership for property buyers.

Furthermore, the 3Rs concept that refers to reduce, reuse and recycle are applied to construction waste management practice. For instance, reduce C\&D waste at the source, reuse and recycling the C\&D waste. Malaysia government work out on the recycle of C\&D waste nevertheless only $15 \%$ of the recycling rate is very low compared to the other developing countries (e.g. Singapore, South Korea and Germany) with range of 50\% to 75\% per year [32]. Reduction considered as the most productive methods on C\&D waste management as generation of waste is reduced and the cost for sorting, transport, disposal and recycling of C\&D waste is reduced in the meantime. The Goodwood Residence located at Kuala Lumpur, Malaysia was constructed with "Zero Waste" concept and $100 \%$ of waste is recycled through 
a demolish system which recycle the aggregates for the use of precast internal partition walls [33].

\subsection{Singapore}

Buildings contribute to approximately one-quarter of the global emission of total carbon dioxide. Singapore is one of the countries which focus on the importance of green building. The government put a lot of effort on it. About $75 \%$ of energy can be saved for new buildings due to the integrated design process, including architects, engineers, contractors, and clients [34]. Other than the design and operation of the building, Singapore's government commenced other policies to enhance the construction of green buildings. In order to improve the application of a variety of green building aspects, technologies and innovations, the Green Mark Scheme (GMS) for building was commenced by the Building and Construction Authority (BCA) in 2005. As the GMS was vigorously promoted, building with green features design is common in Singapore. Buildings with GMS certification are rated based on designated criteria like energy, water, material, cover site, indoor environment and other characteristics of sustainable design [35].

Buildings contribute to approximately one-quarter of the global emission of total carbon dioxide. Singapore is one of the countries which focus on the importance of green building. The government put a lot of effort on it. About $75 \%$ of energy can be saved for new buildings due to the integrated design process, including architects, engineers, contractors, and clients [34]. Other than the design and operation of the building, Singapore's government commenced other policies to enhance the construction of green buildings. In order to improve the application of a variety of green building aspects, technologies and innovations, the Green Mark Scheme (GMS) for building was commenced by the Building and Construction Authority (BCA) in 2005. As the GMS was vigorously promoted, building with green features design is common in Singapore. Buildings with GMS certification are rated based on designated criteria like energy, water, material, cover site, indoor environment and other characteristics of sustainable design [35].

The Building Act (Environmental Sustainability) Regulations 2008 was established to enforce residential and non-residential building must have a Green Mark score of 50 points to get approval from related authorities. The Code for Environmental Sustainability of Buildings under the regulations aimed to reduce the impact of building on the environment and ensure the planning, design and construction of building is eco-friendly (Jain et al., 2020). The criteria under the Code include the concrete usage index (CUI) limit, conservation of present building structure, usage of eco-friendly products under the Singapore Green Labelling Scheme (SGLS) and recycling material [33]. BCA commenced a design guide on use of alternative steel materials to BS5950 [30].

\subsection{Thailand}

Thailand is the only Southeast Asia country that classified C\&D waste as municipal solid waste. Illegal C\&D waste dumping is not allowed in Thailand and local administrations should be responsible for developing ordinance as well as adjusting the solid waste management system like the collection fees for waste are related to the 1992 Environmental Protection Act [36]. There are no recycling centers and disposal sites of C\&D waste in Bangkok, Thailand. 
According to the Public Cleansing Act 1992, the Department of Environment of Bangkok Metropolitan Administration (BMA) is responsible for policy of C\&D waste management and construct waste processing facilities at On-Nuch and Nongkham transfer station [37]. National Integrated Waste Management Plan in Thailand aim to consume natural resources sustainably and the concept of "cradle to cradle" concept by managing the sources of waste generation, promote waste separation for recycling, increase efficiency of waste utilization before final disposal and reduce the total waste generation [36]. Thailand lacks the details information about C\&D waste, so the efficiency of management plan is low.

Based on Table 3, the concept of 3Rs can be found in Malaysia, Singapore and Thailand. Reduce the waste generation at sources, reuse and recycling the C\&D waste. To apply this $3 \mathrm{Rs}$ concept, the data of C\&D waste is required to determine whether the waste is secure for reuse and recycle and to ensure the safety of building. EQA 1974 is the main legislation and regulation which is used to control the impact of construction on the environment. NGTP, GBI, green tax exemption and reduction and investment incentives are the policies that bring Malaysia towards a green building environment by encouraging businessmen and citizens. Singapore has the same idea as Malaysia which is to create a green environment. The difference is Singapore includes the green environment idea to legislation and regulation like the Building Act (Environmental Sustainability) Regulations 2008. BCA in Singapore also launched a guideline for alternative steel material. Lastly, the government of Thailand does not emphasize much on the green building compared to Malaysia and Singapore. The government focuses more on the disposal of C\&D waste.

Table 3. Government policy in different Southeast Asian countries

\begin{tabular}{|c|c|}
\hline Country & $\begin{array}{c}\text { Government Policy } \\
\end{array}$ \\
\hline Malaysia & $\begin{array}{ll} & \text { EQA } 1974 \\
\text { - } & \text { NGTP } \\
\text { - } & \text { GBI } \\
\text { - } & \text { Green tax exemptions and reductions and } \\
\text { investment incentives } \\
\text { - } & \text { 3Rs } \\
\end{array}$ \\
\hline Singapore & $\begin{array}{ll}\text { - } & \text { GMS } \\
\text { - } & \text { Building Act (Environmental Sustainability) } \\
\text { - } & \text { Regulations } 2008 \\
& \text { Code for Environmental Sustainability of } \\
\text { Buildings } \\
\text { Design guide on use of alternative steel } \\
\text { materials } \\
\text { - } 3 \text { Rs } \\
\end{array}$ \\
\hline Thailand & $\begin{array}{l}\text { - } 1992 \text { Environmental Protection Act } \\
\text { - } 3 R s\end{array}$ \\
\hline
\end{tabular}

\section{Green Materials in Southeast Asia}

\subsection{Agricultural waste}

Concrete is one of the essential construction materials: a mixture of cement, sand, water, gravel, and air. It was estimated that around $10 \%$ of total synthetic carbon dioxide $\left(\mathrm{CO}_{2}\right)$ in the atmosphere is generated from concrete production. It is obvious that the amount of $\mathrm{CO}_{2}$ emitted is relatively high. Hence, green concrete is introduced to reduce the generation of $\mathrm{CO}_{2}$. Recently, some study pointed out that the farming waste from the agricultural industry (e.g., 
sugarcane, oil palm, coconut or paddy) shows the potential of making use of the materials in concrete. The agriculture waste with pozzolanic materials can substitute cement, for instance, rice husk ash, wheat straw ash, hazel nutshell ash and sugarcane bagasse ash [38].

\subsection{Rice paddy}

The silica in ceramics can be substituted by using rice husk ash. Rice husk ash is a by-product which can be produced from raw rice paddy through process. The ash under control temperature burning consists of high proportion of non-reactive silica minerals (e.g., cristobalite and tridymite) which can be grinding into tiny particles to develop highly pozzolanic ash and it has reaction with cement in the presence with water. Rice husk ash which consists of $80 \%$ to $95 \%$ of silica is chemical resistance, thermal shock resistance, low thermal conductivity and low mechanical properties, thus it can be used as mineral admixture for cement and concrete [39]. Malaysia, Indonesia and Vietnam which are the Southeast Asia countries have production of rice paddy. As mentioned before, rice husk can be used as substitution of cement. There is a rising commercial value of rice husk and reduced the generation of agricultural waste. During rice milling activities, the rice husk was generated and it does not have any commercial value for businessmen. Table 4 showed the amount of ash can be produced from rice paddy. Among these 3 countries, the production of rice paddy shows an increasing trend from 2002 to 2013. Malaysia (2.7\%) has the least increment and is followed by Vietnam (21.8\%) and Indonesia (43.2\%). Therefore, the rice paddy production showed an increasing trend for the following years as the population increases as mentioned earlier. The production of rice husk is twenty percent of total production of rice paddy in 2013 whereas production of ash is eighteen percent of production of rice husk. Based on the increment trend of production of rice paddy, the substitution of cement with rice husk ash can be widely used in the future.

Table 1. Amount of ash estimate from the production of rice paddy [40]

\begin{tabular}{cccc}
\hline Country & Malaysia & Indonesia & Vietnam \\
\hline Production of rice paddy: & & & \\
- 2002 2013 & $2.7 \mathrm{Mt}$ & $48.7 \mathrm{Mt}$ & $40.0 \mathrm{Mt}$ \\
Production of rice husk & $3.0 \mathrm{Mt}$ & $90.0 \mathrm{Mt}$ & $31.3 \mathrm{Mt}$ \\
Production of rice husk ash & $0.6 \mathrm{Mt}$ & $18.0 \mathrm{Mt}$ & $6.0 \mathrm{Mt}$ \\
Percentage of increment (2002 to 2013) & $0.1 \mathrm{Mt}$ & $3.2 \mathrm{Mt}$ & $1.1 \mathrm{Mt}$ \\
\hline
\end{tabular}

\subsection{Oil palm}

Oil palm shell concrete had been applied widely in Malaysia. This has been seen in case of a $2 \mathrm{~m}$ long footbridge in the University Malaysia Sabah (USM) and the floor with $59 \mathrm{~m}^{2}$ of area of inexpensive house were constructed by using the concrete mix with soil palm shell [41]. The mixture of oil palm in concrete is eco-friendly and more economic. Southeast Asia countries such as Malaysia, Thailand and Indonesia occupied most palm oil production globally. In 2009, the production of oil palm among these 3 countries was almost $90 \%$ of the world which is $49 \%$ for Indonesia, 37\% for Malaysia and 4\% for Thailand [39,40]. Due to the large production of palm oil, the palm oil shell and palm oil clinker waste are large. Palm oil shell and palm oil 
clinker are the agricultural waste used as substitution material to reinforce concrete structural members. The palm oil shell can be obtained by using machinery to break the palm kernel shell whereas palm oil clinker generated through the burning of palm oil waste [41]. Palm oil fuel ash is generated through incineration of palm oil husk or fibers. Similar to rice husk ash, the formation of pozzolans from palm oil fuel ash is the key point. Calcium hydroxide with pozzolanic material (palm oil fuel ash) allows the pozzolanic reaction between silicon dioxide and aluminum oxide to form calcium silicate hydrate. The fineness of ash affects the size of pores in cement paste. Finer ash lowers the size of pores and cement paste has a dense structure and becomes more homogeneous [40].

\subsection{Coconut}

The Philippines and Indonesia are the main producers of coconut in Southeast Asia. In general, coconut shell is disposed of as waste after the coconut meat is removed. The combustion of coconut shell produces coconut shell ash. A research was done to compare the coconut shell concrete beam and conventional concrete beam. The result of the study proves that the concrete beam mix with coconut has similar behaviors with conventional concrete beam but the performance of ultimate torque resistance is good and ductility is higher owing to the long and separate fibers in coconut shell. Another research indicated that coconut shell is a good material for substitution of normal coarse aggregate and widths of crack in experiment are within the limit and have a good performance full strain capacity under flexural loadings [42].

\subsection{Sugarcane}

In Thailand, sugarcane bagasse ash acts as a pozzolanic material mix in cement to have concrete blocks. Sugarcane bagasse ash is also rich with silica which acts as pozzolan to improve the pozzolanic reactions and have a better building material compared with conventional building material. Approximately 0.7 million tons of sugarcane were produced and $270 \mathrm{~kg}$ of bagasse was generated for a metric ton of sugarcane in Malaysia. The production of cane sugar produced waste such as bagasse and leaves. The incineration of sugarcane bagasse produces sugarcane bagasse ash with silicate which can be used as substitution material in cement [43]. In short, rice husk ash, palm oil ash, coconut shell ash and sugarcane bagasse ash are the green material which can be found in Southeast Asia and can be used to replace construction material as shown in Fig. 2. The article reviewed the feasibility of oil palm shell, palm oil clinker and coconut shell suitable to reinforced concrete beam and concrete slab [41]. Agricultural wastes are the by-product of raw material and those waste contain silicate through the combustion or incineration process which can be used to replace the silicate content in cement paste resulting in lightweight green aggregate concrete. These agricultural wastes do not have any commercial value and are disposed of after manufacturing. Hence, improper disposal of agricultural waste might cause environmental pollution and release a stingy smell. As these agricultural wastes are environmentally friendly and contribute to the reduction of the carbon dioxide emission indirectly [41]. 


\subsection{Bamboo}

Besides from agricultural waste, bamboo is considered as one of the green materials which has been widely used in Malaysia. Bamboo can be used as interior decoration, construction of roads and houses [44]. SEAD Build is a company which uses the bamboo as construction material to construct Groove Lounge in Tadom Hill Resort and construct a bamboo bridge as decoration in an office located at Kuala Lumpur, Malaysia by laminated precision-milled bamboo strips together. Bamboo Geotextile Grid Frame System has been commonly applied in Sarawak Malaysia, which uses bamboo to safely support the vertical stress of superimposed load from ground to deep soft subgrade without causing excessive settlement at the right time. For other information, the study of utilization of plastic waste with asphalt for resurfacing roads is ongoing in Malaysia [45].

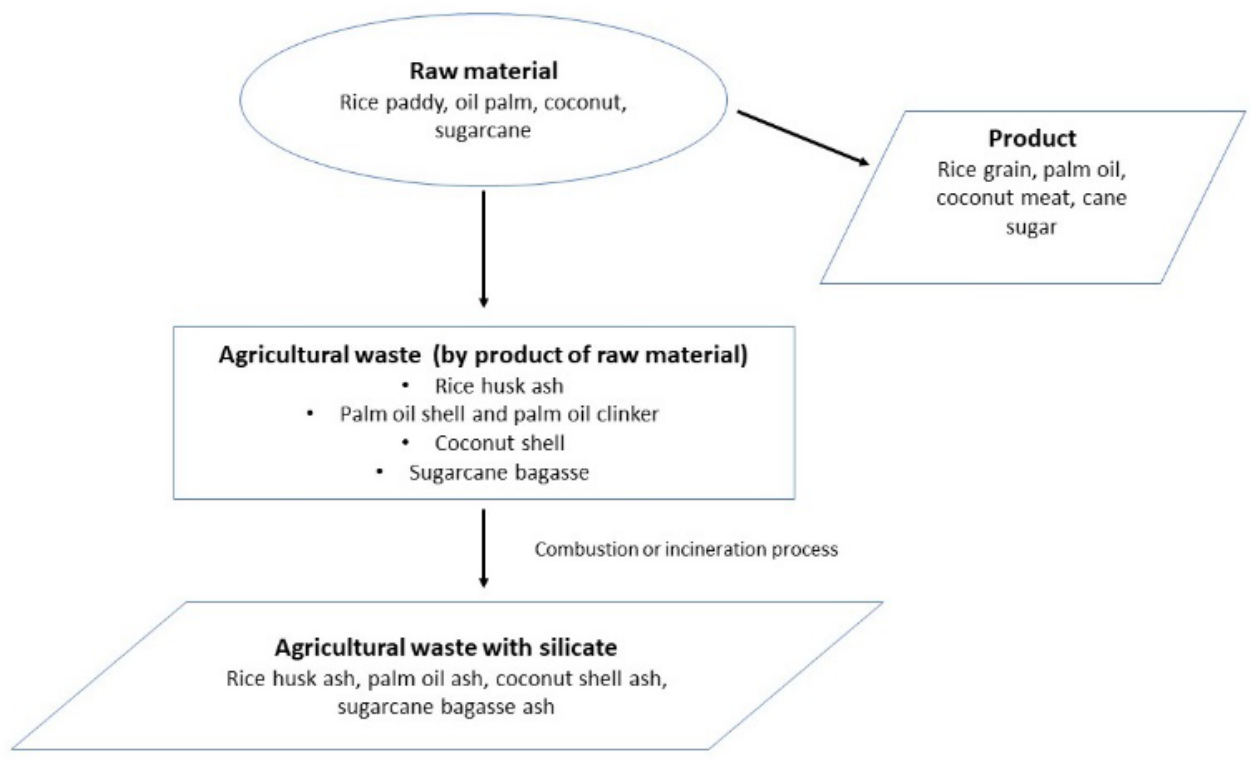

Figure 2. Summary of agricultural waste suitable for construction.

\section{Green Materials Technology in Southeast Asia}

Most of the Southeast Asia countries are moving towards sustainable construction, the development of green technology is the key point. To achieve this, Malaysia commenced a financial initiative named Green Technology Financial Scheme (GFTS) to promote the investment of green technology in the private sector [14].

\subsection{Solar Panel and Solar Thermal Collector}

One of the common green technologies is solar panel. Solar panel consists of photovoltaic cells (solar cells) that converts the sunlight into direct current electricity and it can be seen on the roof of houses or top of buildings to receive maximum solar energy. In Malaysia, the solar panel was installed for light and heater in the home as well as the traffic light and streetlamp. The popularity of solar energy in Malaysia is low as the installation fee and solar electricity is high. To promote solar energy, the government of Malaysia has promoted the $9^{\text {th }}$ and $10^{\text {th }}$ Malaysia Plan with different strategies to attract Malaysian and the result showed a positive 
trend on the government effort as the solar capacity from 2008 to 2017 increased from 9 megawatts to 362 megawatts [46]. In Philippine, the hot water in residential area is supported by integration of solar thermal collector with an auxiliary biomass water heater while integration of desiccant dehumidification system with evaporative and ground cooling system maintain the indoor temperature at $27^{\circ} \mathrm{C}$. Compared with conventional electricity generation (fossil fuel), the solar panel produces clean energy, reduces the emission of carbon dioxide, the energy generation does not have environmental impact, expenses of operation and maintenance are low as well as high availability. On the other hand, the capital cost is high, empty space required for installation and highly dependency on the geographical environment [47].

\subsection{Geothermal technology}

Due to the location of Southeast Asia, geothermal is one of the renewable resources that can be used. The binary cycle power plant with 0.3 -megawatt input produces 127.47 megawatt for bathing, therapy and swimming pool in recreation area and develops a lot of hot spring areas in Thailand. This advantage reduces the dependency on fossil fuel generation in order to decrease the amount of greenhouse gases emitted and attract the tourists to boost the tourism sector in Thailand. In Indonesia, hydrothermal geothermal system is a fully developed technology that utilizes the fluid circulation system with natural convection and withdraws hot water and steam from a permeable reservoir near the surface in high heat. Most of the citizens in Indonesia stay near to the volcano area, hence the exploitation of hydrothermal system is more economic and easier. Furthermore, enhancing the development of binary power plants near to zero or zero emission and land required for geothermal technology is 3 times less than wind energy [48]. However, the geothermal resources release high temperatures of heat which is dangerous compared to the wind and solar energy.

\subsection{Hydropower technology}

Hydropower technology consider as a common technology in Southeast Asia because some countries rely on this clean energy to generate electricity. An article which studies the current status and potential of hydropower development in Southeast Asia. In Malaysia, the usage of fossil fuel slow down after 2005, $10.53 \%$ of electricity generation rely on hydropower technology in 2015 while this is forecasted to reach to $35 \%$ by year of 2030 ; in Indonesia, $10 \%$ of electricity generation rely on the hydropower in 11 years as the country more reliable on the geothermal technology and only small scale of hydropower is promoted; In Thailand, the electricity generation still depending on the fossil fuel and hydropower technology and only $1 / 4$ of theoretical hydropower potential was achieved till 2013; in Myanmar, the only $1 \%$ of hydropower was exploited in 2011 because of the dry season [49]. Although hydropower technology mitigates greenhouse gas emissions from fossil fuel, the construction of hydropower dam creates a negative impact on the environment. To construct a dam large land was cleared lead to soil erosion problem, disruption on the ecosystem near the dam site and the farming land decrease [50].

\subsection{Cooling Roof System}

Cooling roof system aims to lower the energy consumption and decrease overall indoor temperature naturally. In comparison of normal metal roof with metal roof coated with thermal 
reflective coating, $7^{\circ} \mathrm{C}$ (on roof) and $15^{\circ} \mathrm{C}$ (in attic) of temperature is lowered; integration of moving air cavity-solar powered fans lower $1.5^{\circ} \mathrm{C}$ and opened attic inlet design maintain the temperature low in attic. The application of roof system required professional knowledge such as the properties of material and concept of heat and cold flow [50].

\section{Conclusion}

In conclusion, ASEAN countries are striving to move towards sustainable construction with GDP and population growth. In order to achieve the target, the government of Southeast Asia commenced different acts, rules and regulations, tax incentives, investment incentives etc. to encourage the development of a green environment, reduce the negative impact of construction on the environment and decrease the construction waste generation. In Southeast Asia, agricultural waste such as rice husk ash, palm oil shell, palm oil clinker, coconut shell, and sugarcane bagasse can create highly pozzolanic ash to replace the silica in cement paste. This is to mitigate the emission of carbon dioxide sources from the cement making process. However, the cost of green materials is one of the factors that might affect the manufacturer or decision of customers decide to use the materials. The green materials technology emphasizes the solar panel, solar thermal collector, geothermal technology, hydropower technology and cooling roof system. Citizens lack environmental awareness so their government should conduct awareness campaigns. With limited scientific data (impacts of building materials and technologies on the environment), we can refer to the successful examples in other developing countries such as China and Japan to protect our environment and halt the environment's destruction.

\section{Acknowledgement}

The authors thank Curtin University Malaysia for facilitating this work. Collaboration from Yamanashi University Japan is highly appreciated.

\section{Competing Interest}

The authors declare that they have no known competing financial interests or personal relationships that could have appeared to influence the work reported in this paper.

\section{Reference}

[1] Min, V.; Leungbootnak, N.; Srinavin, K.; Aksorn, P.; Deewong, W. (2016). Cambodian construction industry's issues in the ASEAN economic community. Journal of Construction Engineering and Project Management, 1, 1-10.

[2] Department of Statistic Malaysia, Malaysia, Malaysia Economic Performance Fourth Quarter, Accessed on March, 2020 [online]. Available: https://www.dosm.gov.my/

[3] Cimen, O. (2021). Construction and Built Environment in Circular Economy: A Comprehensive Literature Review. Journal of Cleaner Production, 305, 127180, https://doi.org/10.1016/j.jclepro.2021.127180.

[4] Pham, A.D.; Nguyen, Q.T.; Luong, D.L.; Truong, Q.C. (2020). The development of a decision support model for eco-friendly material selection in Vietnam. Sustainability, 12, 2769. https://doi.org/10.3390/su12072769.

[5] Ruben, R.B.; Balaji, S.P.N.; Pranav, K.; Jayasuryaa, J. (2020). Assessment of environmental sustainability for promoting green materials and practices. Mateials Today: Proceedings, https://doi.org/10.1016/j.matpr.2020.09.357. 
[6] Nowotna, A.; Pietruszka, B.; Lisowski, P. (2019). Eco-friendly building materials. IOP Conference Serries: Earth and Environmental Science, 290, 012024.

[7] Zhao, H.; Wang, Y.; Qiu, W.; Qu, W.; Zhang, X. (2018). Research on the application of green building materials in China. IOP Conference Serries: Earth and Environmental Science, 186, 012043.

[8] Iravani, A.; Akbari, M.H.; Zohoori, M. (2017). Advantages and disadvantages of green technology; Goals, challenges and strengths. Interational Journal of Science and Engineering Application, 6, 272-284.

[9] Nong, D.; Wang, C.; Al-Amin, A.Q. (2020). A critical review of energy resources, policies and scientific studies towards a cleaner and more sustainable economy in Vietnam. Renewable and Sustainable Energy Reviews, 134, 110117.

[10] Peng, T.N. (2017). Southeast Asia's demographic situation, regional variations, and national challenges, Southeast Asian Affairs 2017. Berlin, German: ISEAS publisher.

[11] Wang, Y.; Chen, L.; Kubota, J. (2015). The relationship between urbanization, energy use and carbon emissions: evidence from a panel of Association of Southeast Asian Nations (ASEAN) countries. Journal of Cleaner Production, 112, 1368-1374. https://doi.org/10.1016/j.jclepro.2015.06.041.

[12] Luangcharoenrat, C.; Intrachooto, S.; Peansupap, V.; Sutthinarakorn, W. (2019). Factors influencing construction waste generation in building construction: Thailand's perspective. Sustainability, 11,3638. https://doi.org/10.3390/su11133638.

[13] Sist, P. (2000). Reduced-impact logging in the tropics : objectives, principles and impacts. The International Forestry Review, 2: 3-10.

[14] Yusof, N.A.; Awang, H.; Iranmanesh, M. (2017). Determinants and outcomes of environmental practices in Malaysian construction projects. Journal of Cleaner Production, 156: 345-354. https://doi.org/10.1016/j.jclepro.2017.04.064.

[15] Deng, C.; Liu, J.; Nie, X.; Li, Z.; Liu, Y.; Xiao, H.; Hu, X.; Wang, L.; Zhang, Y.; Zhang, G.; Zhu, D.; Xiao, L. (2021). How trade-offs between ecological construction and urbanization expansion affect ecosystem services. Ecological Indicator, 122, 107253. https://doi.org/10.1016/j.ecolind.2020.107253.

[16] Xu, J.; Huang, Y.; Shi, Y.; Deng, Y. (2000). Supply chain management approach for greenhouse and acidifying gases emission reduction towards construction materials industry: A case study from China. Journal of Cleaner Production, 258, 120521. https://doi.org/10.1016/j.jclepro.2020.120521.

[17] Monterrubio, C.; Andriotis, K.; Rodríguez-Muñoz, G. (2020). Residents' perceptions of airport construction impacts: A negativity bias approach. Tourism Management, 77, 103983. https://doi.org/10.1016/j.tourman.2019.103983.

[18] Jittin, V.; Minnu, S.N.; Bahurudeen, A. (2021). Potential of sugarcane bagasse ash as supplementary cementitious material and comparison with currently used rice husk ash. $\begin{array}{lllll}\text { Construction and } & \text { Building }\end{array}$ https://doi.org/10.1016/j.conbuildmat.2020.121679.

[19] Aslam, M.S.; Huang, B.; Cui, L. (2020). Review of construction and demolition waste management in China and USA. Journal of Environmental Management, 264, 110445. https://doi.org/10.1016/j.jenvman.2020.110445.

[20] Hoang, N.H.; Ishigaki, T.; Kubota, R.; Yamada, M.; Kawamoto, K. (2020). A review of construction and demolition waste management in Southeast Asia. Journal of Material Cycles and Waste Management, 22, 315-325. https://doi.org/10.1007/s10163-019-00914-5.

[21] Salim, H.K.; Padfield, R.; Hansen, S.B.; Mohamad, S.E.; Yuzir, A.; Syayuti, K.; Tham, M.H.; Papargyropoulou, E. (2018). Global trends in environmental management system and ISO14001 research. Journal of Cleaner Production, 170, 645-653. https://doi.org/10.1016/j.jclepro. 2017.09.017.

[22] Dash, K.; Bhattacharyya, P.; Roy, K.S.; Neogi, S.; Nayak, A.K. (2019). Environmental constraints' sensitivity of soil organic carbon decomposition to temperature, management practices and climate change. Ecological Indicator, 107, 105644. https://doi.org/10.1016/j. ecolind.2019.105644.

[23] Walker, A.M.; Vermeulen, W.J.V.; Simboli, A.; Raggi, A. (2021). Sustainability assessment in circular inter-firm networks: An integrated framework of industrial ecology and circular supply 
chain management approaches. Journal of Cleaner Production, 286, 125457. https://doi.org/10.1016/j. jclepro.2020.125457.

[24] United Nations. (2020). Sustainable development goals. Accessed on March, 2020 [online]. Available: https://www.un.org/sustainabledevelopment/

[25] Treacy, R.; Humphreys, P.; McIvor, R.; Lo, C. (2019). ISO14001 certification and operating performance: A practice-based view. International Journal of Production Economy, 208, 319328. https://doi.org/10.1016/j.ijpe.2018.12.012.

[26] Memon, P.A. (2000). Devolution of environmental regulation: environmental impact assessment in Malaysia. Impact Assessment and Project Appraisal, 18, 283-293. https://doi.org/10.3152/147154600781767295.

[27] Briffett, C.; Obbard, J.; Mackee, J. (2004). Environmental assessment in Malaysia: a means to an end or a new beginning?. Impact Assessment and Project Appraisal, 22, 221-233. https://doi.org/10.3152/147154604781765923.

[28] Mustafa, M. (2012). The environmental quality act 1974: A significant legal instrument for implementing environmental policy directives of Malaysia, IIUM Law Journal, 19. https://doi.org/10.31436/iiumlj.v19i1.1.

[29] Onuoha, I.J.; Kamarudin, N.; Aliagha, G.U.; Okeahialam, S.A.; Atilola, M.I.; Atamamen, F.O. (2017). Developing policies and programmes for green buildings: What can Nigeria learn from Malaysia's experience?. International Journal of Real Estate Studies, 11, 50-58.

[30] Azis, S.S.A. (2021). Improving present-day energy savings among green building sector in Malaysia using benefit transfer approach: Cooling and lighting loads. Renewable and Sustainable Energy Reviews, 137, 110570. https://doi.org/10.1016/j.rser.2020.110570.

[31] Aliagha, G. U.; Hashim, M.; Sanni, A.O.; Ali, K. N. (2013). Review of green building demand factors for Malaysia. Journal of Energy Technologies and Policy, 3, 471-478.

[32] Yusof, N.A.; Awang, H.; Iranmanesh, M. (2017). Determinants and outcomes of environmental practices in Malaysian construction projects. Journal of Cleaner Production, 156, 345-354. https://doi.org/10.1016/j.jclepro.2017.04.064.

[33] Chew, K.C. (2010). Singapore's strategies towards sustainable construction. IES Journal Part A: Civil \& Structural Engineering, 3, 196-202. https://doi.org/10.1080/19373260.2010.491641.

[34] Zhang, D.; Tu, Y. (2021). Green building, pro-environmental behavior and well-being: Evidence from Singapore. Cities, 108, 102980. https://doi.org/10.1016/j.cities.2020.102980.

[35] Jain, M.; Siva, V.; Hoppe, T.; and Bressers, H. (2020). Assessing governance of low energy green building innovation in the building sector: Insights from Singapore and Delhi. Energy Policy, 145, 111752. https://doi.org/10.1016/j.enpol.2020.111752.

[36] Kofoworola, O.F.; Gheewala, S.H. (2009). Estimation of construction waste generation and management in Thailand. Waste Manage, 731-738. https://doi.org/10.1016/j.wasman.2008.07.004.

[37] Thongkamsuk, P.; Sudasna, K.; Tondee, T. (2017). Waste generated in high-rise buildings construction: A current situation in Thailand. Energy Procedia, 138, 11-416. https://doi.org/10.1016/j.egypro.2017.10.186.

[38] Aghdam, K.A.; Rad, A.F.; Shakeri, H.; Sardroud, J.M. (2018). Approaching green buildings using eco-efficient construction materials: A review of the state-of-the-art. Journal of Construction Engineering and Project Management, 8, 1-23, https://doi.org/10.6106/JCEPM.2018.8.3.001.

[39] Hossain, S.S.; Mathur, L.; Roy, P.K. (2018). Rice husk/rice husk ash as an alternative source of silica in ceramics: A review. Journal of Asian Ceramic Society, 6, 299-313. https://doi.org/10.1080/21870764.2018.1539210.

[40] Aprianti, E.; Shafigh, P.; Bahri, S.; Farahani, J.N. (2015). Supplementary cementitious materials origin from agricultural wastes-A review. Construction and Building Materials, 74, 176-187. https://doi.org/10.1016/j.conbuildmat.2014.10.010.

[41] Mo, K.H.; Alengaram, U.J.; Jumaat, M.Z. (2014). A review on the use of agriculture waste material as lightweight aggregate for reinforced concrete structural members. Advances in Materials Science and Engineering, 2014, 365197. https://doi.org/10.1155/2014/365197.

[42] Palanisamy, M.; Kolandasamy, P.; Awoyera, P.; Gobinath, R.; Muthusamy, S.; Krishnasamy, T. R.; Viloria, A. (2020). Permeability properties of lightweight self-consolidating concrete made with coconut shell aggregate. Journal of Materials Research and Technology, 9, 3547-3557. https://doi.org/10.1016/j.jmrt.2020.01.092. 
[43] Sahiron, N.; Rahmat, N.; Hamzah, F. (2016). Characterization of sodium silicate derived from sugarcane bagasse ash. Malaysian Journal of Analitical Science, 21, 512-517. http://dx.doi.org/10.17576/mjas-2017-2102-26.

[44] Adamu, M.; Rahman, M.R.; Hamdan, S.; Bakri, M.K.; Yusof, F.A.M. (2020). Impact of polyvinyl alcohol/acrylonitrile on bamboo nanocomposite and optimization of mechanical performance by response surface methodology. Construction and Building Materials, 258, 119693. https://doi.org/10.1016/j.conbuildmat.2020.119693.

[45] Kamar, K.A.M.; Hamid, Z.A. (2011). Sustainability today: Sustainable construction and green building: The case of Malaysia. WIT Transaction Ecology and The Environment, 167, 15-22.

[46] Soonmin, H.; Lomi, A.; Okoroigwe, E.C.; Urrego, L.R. (2019). Investigation of solar energy: The case study in Malaysia, Indonesia, Colombia and Nigeria. International Journal of Renewable Energy Research, 9: 86-95.

[47] Sampaio, P.G.V.; González, M.O.A. (2017). Photovoltaic solar energy: Conceptual framework. Renewable and Sustainable Energy Reviews, 74, 590-601. https://doi.org/10.1016/j.rser.2017.02.081.

[48] Fan, K.; Nam, S. (2018). Accelerating geothermal development in Indonesia: A case study in the underutilization of geothermal energy. Consilience, 19, 103-129.

[49] Tang, S.; Chen, J.; Sun, P.; Li, Y.; Yu, P.; Chen, E. (2019). Current and future hydropower development in Southeast Asia countries (Malaysia, Indonesia, Thailand and Myanmar). Energy Policy, 129, 239-249. https://doi.org/10.1016/j.enpol.2019.02.036.

[50] Erdiwansyah; Mahidin, R.; Mamat, M.S.M.; Sani, F.; Khoerunnisa, Kadarohman, A. (2019). Target and demand for renewable energy across 10 ASEAN countries by 2040. The Electrical Journal, 32, 106670. https://doi.org/10.1016/j.tej.2019.106670. 